\title{
Liquid Phase Hydrogenation of Nitrobenzene over Nickel Supported on Titania
}

\author{
K. Joseph Antony RAJ ${ }^{1}$, M. G. PRAKASH ${ }^{1,2}$, R. MAHALAKSHMY ${ }^{2}$, T. ELANGOVAN ${ }^{1}$, \\ B. VISWANATHAN ${ }^{1, *}$ \\ ${ }^{1}$ National Centre for Catalysis Research, Indian Institute of Technology-Madras, Chennai 600036, India \\ ${ }^{2} P G \&$ Research Department of Chemistry, Thiagarajar College, Madurai 625009, India
}

\begin{abstract}
The catalytic hydrogenation of nitrobenzene to aniline employing nickel impregnated on rutile, anatase, and high surface area titania supports has been investigated. The nickel is present in elemental state as fcc phase on the catalyst as evidenced by X-ray diffraction results. The Ni crystallite size was found to be greater for Ni/anatase. The temperature-programmed reduction results suggest a greater metal-support interaction for $\mathrm{Ni} /$ rutile. The observed order of catalytic activity for the hydrogenation of nitrobenzene is $\mathrm{Ni} /$ rutile $>\mathrm{Ni} /$ anatase $>\mathrm{Ni} / \mathrm{TiO}_{2}$. A conversion of $99 \%$ was observed for $\mathrm{Ni} /$ rutile at $140{ }^{\circ} \mathrm{C}$ and hydrogen pressure of $1.96 \mathrm{MPa}$. Interestingly, aniline is the only product formed which demonstrates the catalytic hydrogenation of nitrobenzene proceeds with atom economy. Both Ni/rutile and Ni/anatase exhibited a better stability than $\mathrm{Ni} / \mathrm{TiO}_{2}$. The hydrogenation proceeds with the preferential adsorption of hydrogen on nickel present in the catalyst surface, possibly assisted by $\mathrm{TiO}_{x}$ species.
\end{abstract}

Key words: hydrogenation; nitrobenzene; nickel; titania; aniline

CLC number: O643 Document code: A

Received 2 March 2012. Accepted 25 April 2012.

*Corresponding author.Tel: +91-44-22574241; Fax: +91-44-22574202; E-mail: bvnathan@iitm.ac.in

This work was supported by Department of Science and Technology, Government of India.

English edition available online at Elsevier ScienceDirect (http://www.sciencedirect.com/science/journal/18722067).

Catalytic hydrogenation is a promising process as it does not generate acid effluents, and has little impact on environment. The Ni/Titania catalysts find wide applications in the hydrogenation of organic intermediates which are largely used in diverse industries. Titania offers itself as good catalyst support by virtue of strong metal support interaction (SMSI). The catalytic hydrogenation of nitrobenzene (NB) yields aniline (AN), a valuable intermediate for producing agricultural products, dyes, explosives, pharmaceuticals, and polyurethanes [1]. Conventional non-catalytic processes using either Bechamp reaction or sulphide reduction produce a large amount of waste [2]. Commercially, hydrogenation of NB is performed in the vapour phase over copper-based catalysts [3]. The metal supported catalysts such as Pd [4], Pt [5], Rh [6], and Re [7] have been studied for the reduction of nitro compounds. Holler et al. [8] showed a $100 \%$ yield of AN on Pd- and Pt-supported woven glass fibres at $50{ }^{\circ} \mathrm{C}$ and $7 \times 10^{5} \mathrm{~Pa}$ hydrogen pressure. Zhao et al. [9] reported a maximum NB conversion of $73 \%$ and $56 \%$ of AN selectivity on $\mathrm{Pt} / \mathrm{C}$ at $35{ }^{\circ} \mathrm{C}$ and $4 \mathrm{MPa}$ hydrogen pressure. However, their large-scale production has not materialized due to high costs. The other metals like Co [10], Zn [11], Sn [12], and Mo [13] have also been examined for the hydrogenation of nitroarenes. Junge et al. [14] examined the iron-catalysed reduction of nitro compounds to the corresponding amines. The iron-based catalysts are more in the limelight of catalytic reduction of nitrobenzenes [15]. Li et al. [16] and Xu et al. [17] examined the hydrogenation of NB over the Ni based catalysts and showed a $100 \%$ of AN selectivity on mesoporous $\mathrm{Ni}-\mathrm{B}$ at $90{ }^{\circ} \mathrm{C}$ and 1 MPa hydrogen pressure. Vilella et al. [18] reported the hydrogenation of NB over Pt/C catalysts with a lower selectivity for AN. Sun et al. [19] examined the NB reduction over the Pt-supported on multi-walled carbon nanotubes and showed a conversion and selectivity of $100 \%$ respectively for $\mathrm{NB}$ and $\mathrm{AN}$ at $60{ }^{\circ} \mathrm{C}$ and $4 \mathrm{MPa}$ hydrogen pressure. Meng et al. [20] reported NB reduction over $\mathrm{Ni} / \mathrm{Al}_{2} \mathrm{O}_{3}$ and showed a conversion of $13 \%-73 \%$ and $62 \%-99 \%$ of AN selectivity at $50{ }^{\circ} \mathrm{C}$ and $4 \mathrm{MPa}$ hydrogen pressure. Due to the importance of selective reduction of aromatic nitro compounds, the study for improved methods remains an objective.

The present work aims to systematically study the liquid phase hydrogenation of NB into AN employing Ni-supported on various phases of titania namely, rutile, anatase, and high surface area. This paper also compares the activity of amorphous titania with the crystalline one in the NB hydrogenation. We have demonstrated the formation of AN 
with atom economy. In addition, the catalyst stability is investigated.

\section{Experimental}

\subsection{Chemicals}

Rutile $\mathrm{TiO}_{2}$ (Aldrich), anatase $\mathrm{TiO}_{2}$ (Aldrich), $\mathrm{Ni}\left(\mathrm{NO}_{3}\right)_{2}$. $6 \mathrm{H}_{2} \mathrm{O}$ (Qualigens), nitrobenzene (Qualigens), aniline (Qualigens), ethanol (Qualigens), and high surface area $\mathrm{TiO}_{2}$ [21] were used without further purification. Water used as solvent in the study is doubly distilled.

\subsection{Preparation of catalysts}

The various forms of titania (anatase, rutile, and high surface area) support were impregnated with nickel by incipient wetness impregnation method using $\mathrm{Ni}\left(\mathrm{NO}_{3}\right)_{2} \cdot 6 \mathrm{H}_{2} \mathrm{O}$. In a typical synthesis, $2 \mathrm{~g}$ of anatase was mixed with $30 \mathrm{~g}$ of distilled water. $\mathrm{Ni}\left(\mathrm{NO}_{3}\right)_{2} \cdot 6 \mathrm{H}_{2} \mathrm{O}(1.48 \mathrm{~g})$ was added to this mixture, and heated to $70-80{ }^{\circ} \mathrm{C}$ with stirring for $5-6 \mathrm{~h}$. The slurry was filtered and dried at $100{ }^{\circ} \mathrm{C}$ for $12 \mathrm{~h}$. The dried sample was calcined at $500{ }^{\circ} \mathrm{C}$ in flowing air for $2 \mathrm{~h}$ (Ni/anatase-500). Following the same procedure, nickel impregnated rutile support (Ni/rutile-500) and high surface area titania support $\left(\mathrm{Ni} / \mathrm{TiO}_{2}-500\right)$ were prepared. The numbers in the abbreviations denote the temperature of calcination. The nickel contents of all the catalysts are $15 \mathrm{wt} \%$, as determined by X-ray fluorescence (XRF) analysis. All the catalyst samples were reduced under hydrogen flow at 450 ${ }^{\circ} \mathrm{C}$ in a tubular reactor with a heating rate of $10{ }^{\circ} \mathrm{C} / \mathrm{min}$. The reduced samples were used in the NB hydrogenation study. A suffix of $450 \mathrm{R}$ is appended to the abbreviation to denote the reduced samples.

\subsection{Characterization of Catalysts}

Wide-angle X-ray diffraction (XRD) patterns for the calcined samples were obtained using a Rigaku Miniflex II, using $\mathrm{Cu} K_{\alpha}$ radiation. The average crystallite size was calculated using Scherrer equation. The nickel contents of the catalysts were analyzed on Rigaku XRF spectrometer. Transmission electron microscopy (TEM) of the samples was performed on a CM 20 Phillips transmission electron microscope with an acceleration voltage of $200 \mathrm{KV}$. Sample preparation for TEM involved ultrasonic dispersion of the sample in methanol and placing a drop of the suspension on a carbon-coated copper grid and drying under room temperature in vacuum. Fourier transform infrared (FT-IR) spectra for the samples were recorded using a Bruker Tensor-27 instrument. The nitrogen adsorption-desorption isotherms were measured at $-196{ }^{\circ} \mathrm{C}$ using a Micromeritics
ASAP 2020 surface area and porosity analyzer after the samples were degassed in vacuum at $300^{\circ} \mathrm{C}$ for $3 \mathrm{~h}$. Specific surface area was calculated from the BET plot. Pore volume was measured at the single point of $p / p_{0}=0.99$. Hydrogen temperature-programmed reduction $\left(\mathrm{H}_{2}\right.$-TPR) was carried out in a quartz reactor using Micromeritics autochem II chemisorption analyzer.

\subsection{Catalytic studies}

Liquid phase NB hydrogenation was performed at $140{ }^{\circ} \mathrm{C}$ and $1.96 \mathrm{MPa}$ of hydrogen pressure in a $100 \mathrm{ml}$ Parr autoclave. Before the reaction, the autoclave was purged with nitrogen and thereafter pressurized with hydrogen. The autoclave was charged with $0.15 \mathrm{~g}$ of Ni-supported titania catalyst, $2 \mathrm{~g}$ of NB , and $40 \mathrm{ml}$ of ethanol. The reaction was performed for $1 \mathrm{~h}$ while stirring the reaction mixture at 400 $\mathrm{r} / \mathrm{min}$. After each reaction, the autoclave was cooled to 30 ${ }^{\circ} \mathrm{C}$. The reaction products were separated by filtration and analyzed on PerkinElmer Clarus-500 GC equipped with ZB-1 capillary column (30 m, stationary phase thickness $0.25 \mu \mathrm{m}$ ) and FID. A temperature programme of $10{ }^{\circ} \mathrm{C} / \mathrm{min}$ from 50 to $250{ }^{\circ} \mathrm{C}$ was employed. The sample $(0.1 \mu \mathrm{l})$ was injected with a split ratio set at 1:100. The reaction products were identified by GC-MS.

\section{Results and discussion}

\subsection{XRD results}

The XRD patterns of nickel impregnated on various phases of titania and calcined at $500{ }^{\circ} \mathrm{C}$ for $2 \mathrm{~h}$ are shown in Fig. 1 . The $\mathrm{Ni} / \mathrm{TiO}_{2}-500$ sample showed reflections at $2 \theta$ of $25.3^{\circ}, 38.3^{\circ}$, and $48.1^{\circ}$ which are characteristic of anatase phase of titania. In addition, there is a reflection appearing

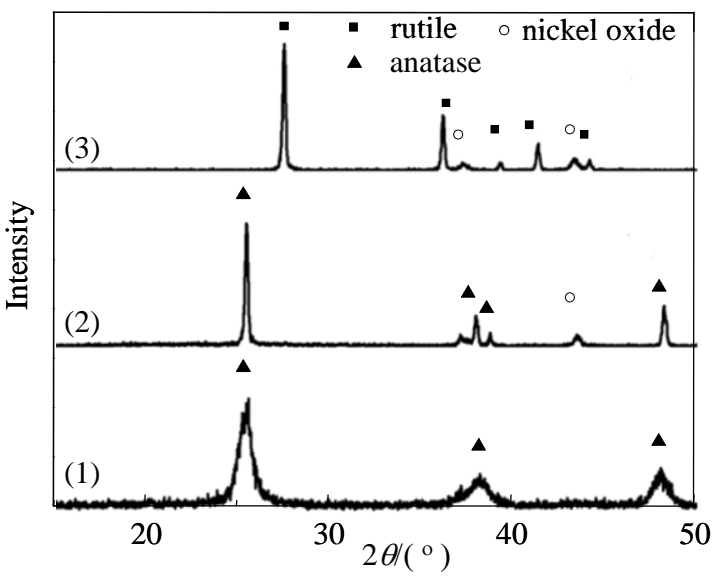

Fig. 1. XRD patterns of various phases of titania impregnated with nickel and calcined at $500{ }^{\circ} \mathrm{C}$ for 2 h. (1) $\mathrm{Ni} / \mathrm{TiO}_{2}-500$; (2) Ni/anatase-500; (3) Ni/rutile-500. 
as a shoulder at $37.3^{\circ}$ which is characteristic of $\mathrm{NiO}$. This reflection becomes prominent in case of $\mathrm{Ni} /$ anatase- 500 and $\mathrm{Ni} /$ rutile-500, with an additional reflection at $43.3^{\circ}$. The other reflections for $\mathrm{Ni} /$ anatase-500 at $25.3^{\circ}, 37^{\circ}, 37.8^{\circ}$, $38.6^{\circ}$, and $48.2^{\circ}$ are due to anatase phase of titania. The reflections observed for $\mathrm{Ni} /$ rutile-500 at $27.5^{\circ}, 36.2^{\circ}, 39.4^{\circ}$, $41.3^{\circ}$, and $44.1^{\circ}$ are characteristic of rutile phase of titania. The characteristic reflections due to nickel titanate at $2 \theta$ of $24.5^{\circ}, 33.4^{\circ}$, and $49.7^{\circ}$ were not observed in the samples, which shows that nickel titanate is not formed when calcined at $500{ }^{\circ} \mathrm{C}$.

Figure 2 displays the XRD patterns of nickel impregnated on various phases of titania and calcined at $500{ }^{\circ} \mathrm{C}$ for $2 \mathrm{~h}$ and thereafter reduced at $450{ }^{\circ} \mathrm{C}$ under flowing hydrogen for $4 \mathrm{~h}$. The XRD patterns of all the samples showed a broad reflection at $2 \theta=44.5^{\circ}$, which is characteristic of $f c c$ phase of Ni. The hcp phase of Ni was not formed for these samples because its characteristic reflection was not observed at $2 \theta=41.7^{\circ}$. The $\mathrm{Ni} /$ anatase-500 and $\mathrm{Ni} /$ rutile-500 samples exhibit reflections at $2 \theta$ of $37.3^{\circ}$ and $43.3^{\circ}$ for samples that are only calcined (Fig. 1), which are characteristic of $f c c$ phase of NiO species (JCPDS 89-5881). These reflections are not seen in the reduced samples, which show the com-

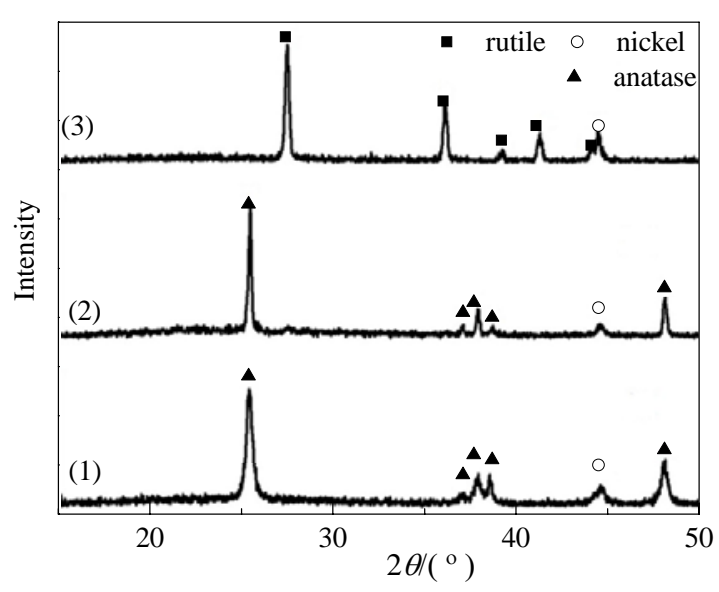

Fig. 2. XRD patterns of nickel impregnated on various phases of titania and calcined at $500{ }^{\circ} \mathrm{C}$ for $2 \mathrm{~h}$ and reduced at $450{ }^{\circ} \mathrm{C}$ for $4 \mathrm{~h}$. (1) $\mathrm{Ni} / \mathrm{TiO}_{2}-500-450 \mathrm{R}$; (2) Ni/anatase-500-450R; (3) Ni/rutile-500-450R.

Table 1 Specific surface area, pore volume, and crystallite size of Ni and titania

\begin{tabular}{lcccc}
\hline \multirow{2}{*}{ Sample } & $\begin{array}{c}\text { Specific surface } \\
\text { area }\left(\mathrm{m}^{2} / \mathrm{g}\right)\end{array}$ & $\begin{array}{c}\text { Pore volume } \\
\left(\mathrm{cm}^{3} / \mathrm{g}\right)\end{array}$ & \multicolumn{2}{c}{ Crystallite size } \\
\cline { 5 - 6 } $\mathrm{Ni} / \mathrm{TiO}_{2}-500$ & 44 & 0.13 & - & $\mathrm{TiO}_{2}$ \\
$\mathrm{Ni} / \mathrm{TiO}_{2}-500-450 \mathrm{R}$ & 32 & 0.11 & 15.4 & 22.5 \\
$\mathrm{Ni} /$ anatase-500 & 10 & 0.07 & - & 47.5 \\
$\mathrm{Ni} /$ anatase-500-450R & 13 & 0.08 & 23.3 & 46.0 \\
$\mathrm{Ni} /$ rutile-500 & 10 & 0.06 & - & 49.3 \\
$\mathrm{Ni} /$ rutile-500-450R & 16 & 0.08 & 16.4 & 36.7 \\
\hline
\end{tabular}

plete reduction of $\mathrm{NiO}$. The crystallite sizes for the reduced samples were calculated using Scherrer equation (Table 1). An evaluation of crystallite sizes of $\mathrm{Ni}$ shows nearly same crystallite sizes for $\mathrm{Ni} / \mathrm{TiO}_{2}-500(15.4 \mathrm{~nm})$ and $\mathrm{Ni} /$ rutile-500 $(16.4 \mathrm{~nm})$, while it was greater for $\mathrm{Ni} /$ anatase-500 (23.3 $\mathrm{nm})$. It is anticipated that anatase and rutile show similar crystallite sizes for $\mathrm{Ni}$, however, the smaller crystallite size of $\mathrm{Ni}$ on rutile than anatase may be due to the overlapping of $2 \theta$ reflections at $44.5^{\circ}$ for $\mathrm{Ni}$ and $44.2^{\circ}$ for rutile.

The evaluation of XRD patterns of the reduced samples which are calcined at $500{ }^{\circ} \mathrm{C}$ showed a decrease in crystallinity of $28 \%$ and $61 \%$ for anatase and rutile, respectively, while an enhancement in crystallinity (45\%) was observed for high surface area titania. The XRD patterns suggest that all the $\mathrm{Ni}$ atoms on the surface of the three samples are in their elemental state, as discerned from the disappearance of $\mathrm{NiO}$ reflections and emergence of $\mathrm{Ni}^{0}$ reflection. The samples which are only calcined at $500{ }^{\circ} \mathrm{C}$ (i.e. not reduced) did not show any change in crystallinity. However, the reduction of the samples showed a twofold decrease in crystallinity for $\mathrm{Ni} /$ rutile-500 than $\mathrm{Ni} /$ anatase-500. This demonstrates a greater interaction of $\mathrm{Ni}$ with rutile than with anatase.

\subsection{DRIFT results}

The DRIFT spectra obtained for the nickel supported titania samples are presented in Fig. 3. The DRIFT spectra of $\mathrm{TiO}_{2}$ and $\mathrm{NiO}$ are also given for purpose of reference. In case of $\mathrm{Ni} / \mathrm{TiO}_{2}-100$ absorptions are observed in the region of $1250-1750 \mathrm{~cm}^{-1}$ which is essentially due to the presence of bulk $\mathrm{NiO}$ in the sample, as the spectrum is comparable with $\mathrm{NiO}$ (Fig. 3(4)). Similarly, $\mathrm{Ni}^{-} \mathrm{TiO}_{2}-500$ also showed absorptions at 1354 and $1607 \mathrm{~cm}^{-1}$ characteristic of $\mathrm{NiO}$. On the other hand, the XRD pattern obtained for $\mathrm{Ni} / \mathrm{TiO}_{2}-500$ did not have reflections due to $\mathrm{NiO}$, which may be due to

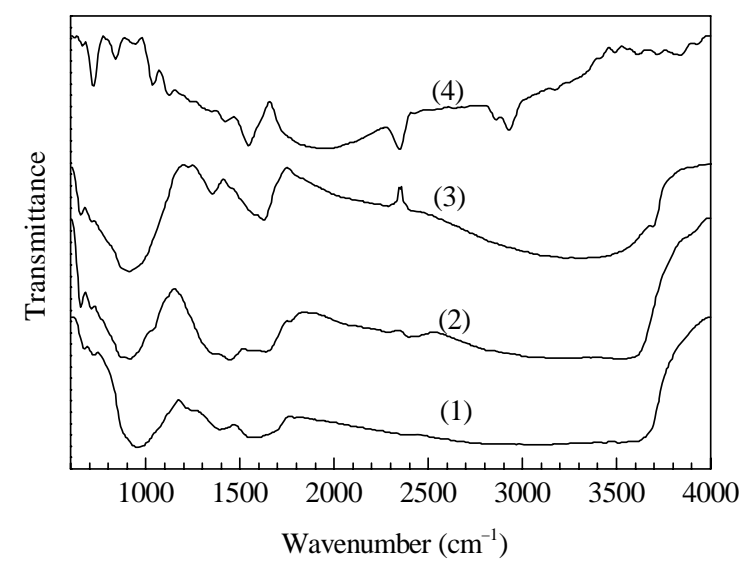

Fig. 3. DRIFT spectra of the nickel supported on high surface area $\mathrm{TiO}_{2}$ calcined at various temperatures. (1) $\mathrm{TiO}_{2}$; (2) Ni/TiO -100 ; (3) $\mathrm{Ni} / \mathrm{TiO}_{2}-500$; (4) NiO. 
greater dispersion of $\mathrm{NiO}$ or the absence of $\mathrm{NiO}$ species on the surface of the sample. The DRIFT spectral profiles obtained for $\mathrm{Ni} /$ anatase and $\mathrm{Ni} /$ rutile samples were found to be similar to $\mathrm{Ni} / \mathrm{TiO}_{2}$ in the region of $1250-1750 \mathrm{~cm}^{-1}$. It may be noted that, $\mathrm{Ni} /$ rutile showed a greater decrease in intensity than $\mathrm{Ni} /$ anatase when calcined at $500{ }^{\circ} \mathrm{C}$ suggesting an enhanced interaction of $\mathrm{NiO}$.

\subsection{TPD results}

The TPD profiles of $\mathrm{Ni} / \mathrm{TiO}_{2}, \mathrm{Ni} /$ anatase, and $\mathrm{Ni} /$ rutile calcined at $500{ }^{\circ} \mathrm{C}$ are shown in Fig. 4. It was found that $\mathrm{Ni} / \mathrm{TiO}_{2}-500$ could be reduced at lower temperature than $\mathrm{Ni} /$ anatase-500 and $\mathrm{Ni} /$ rutile-500, and $\mathrm{Ni} /$ rutile displayed a broader TPR profile than $\mathrm{Ni} / \mathrm{TiO}_{2}$ and $\mathrm{Ni} /$ anatase. The $\mathrm{Ni}$ modified anatase and rutile showed three stage reduction with a peak reduction at 380 and $351{ }^{\circ} \mathrm{C}$, respectively. A lower peak reduction temperature exhibited by rutile suggests a greater reducible activity of rutile than anatase. The observation of multiple stages of reduction for the Ni present in anatase and rutile is essentially attributed to the formation of nickel titanate. The TPR profiles of nickel supported on various phases of titania showed that $\mathrm{Ni} / \mathrm{TiO}_{2}$ could be fully reduced at $382{ }^{\circ} \mathrm{C}$ while $\mathrm{Ni} /$ anatase and $\mathrm{Ni} /$ rutile are fully reduced at 437 and $464{ }^{\circ} \mathrm{C}$, respectively. A higher complete reduction temperature observed for $\mathrm{Ni} /$ rutile suggests a stronger metal-support interaction than $\mathrm{Ni} /$ anatase and $\mathrm{Ni} / \mathrm{TiO}_{2}$. It may be noted that the XRD patterns obtained for the samples calcined at $500{ }^{\circ} \mathrm{C}$ did not suggest the formation of nickel titanate. Nevertheless, the TPR profiles showed reduction in multiple stages for the $\mathrm{Ni} /$ anatase and $\mathrm{Ni} /$ rutile, suggesting the formation of nickel titanate.

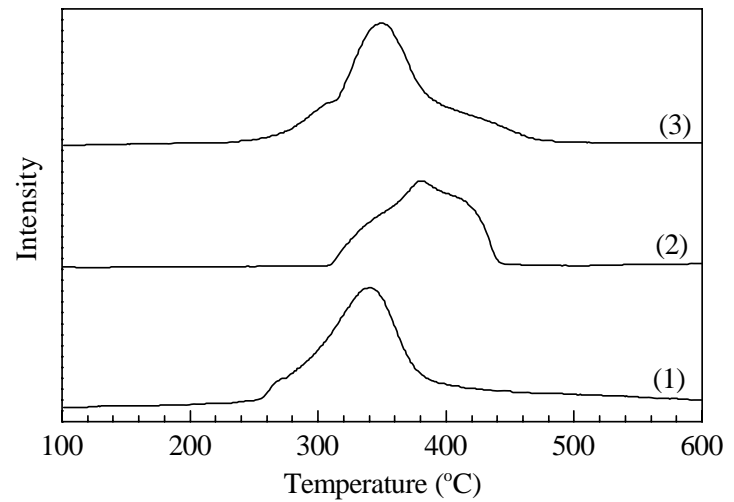

Fig. 4. TPR profiles of $\mathrm{Ni}$ impregnated on various phases of titania calcined at $500{ }^{\circ} \mathrm{C}$ for 2 h. (1) $\mathrm{Ni} / \mathrm{TiO}_{2}-500$; (2) Ni/anatase-500; (3) $\mathrm{Ni}$ /rutile-500.

\subsection{TEM results}

Figure 5 shows TEM images with different magnifica-
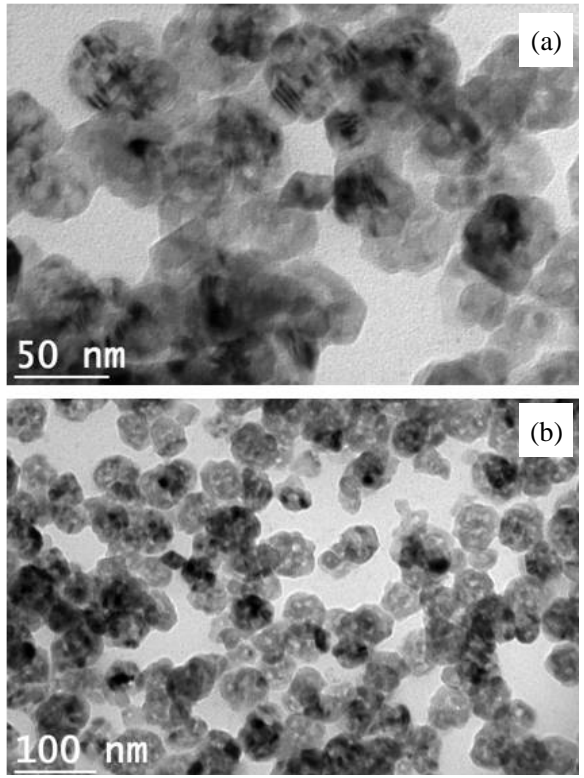

Fig. 5. TEM images of $\mathrm{Ni} / \mathrm{TiO}_{2}-500-450 \mathrm{R}$ with different magnifications.

tions for reduced $\mathrm{Ni} / \mathrm{TiO}_{2}-500$ sample. The sample is composed of many small particles which are nearly monodisperse with average particle diameters of 40 and $50 \mathrm{~nm}$. This particle size is measured only for the titania support and particle size of Ni could not be measured because of the greater dispersion of $\mathrm{Ni}$ in the support. The sharp boundaries of the particles demonstrate crystalline characteristics of the sample. The images show spherical morphology for $\mathrm{Ni} / \mathrm{TiO}_{2}$ particles.

\subsection{Specific surface area and pore volume}

The specific surface area and pore volume of the nickel supported on $\mathrm{TiO}_{2}$, anatase, and rutile calcined at $500{ }^{\circ} \mathrm{C}$ and thereafter reduced at $450{ }^{\circ} \mathrm{C}$ under flowing hydrogen are shown in Table 1 . The specific surface area of the unmodified supports of $\mathrm{TiO}_{2}$, anatase, and rutile were, respectively, 275, 12, and $11 \mathrm{~m}^{2} / \mathrm{g}$. An inspection of the table reveals that the surface area of unmodified $\mathrm{TiO}_{2}$ is greatly reduced on impregnation with $\mathrm{Ni}$. In case of $\mathrm{Ni} / \mathrm{TiO}_{2}-500$, the specific surface area was found to decrease on reducing the sample. The decrease in the surface area could be due to aggregation of particles leading to lowering of porosity of the samples. On the other hand, there was a marginal increase in specific surface area for $\mathrm{Ni} /$ anatase and $\mathrm{Ni} /$ rutile on reduction. The specific surface area of the reduced samples follow the order $\mathrm{Ni} / \mathrm{TiO}_{2}>\mathrm{Ni} /$ rutile $>\mathrm{Ni}$ /anatase. There was a decrease in pore volume with reduction for $\mathrm{Ni} / \mathrm{TiO}_{2}$ while it remains more or less the same with $\mathrm{Ni}$ /anatase and $\mathrm{Ni} /$ rutile. The $\mathrm{Ni}$ crystallite size, measured for the reduced samples, follows the order of $\mathrm{Ni} /$ anatase $>$ 
$\mathrm{Ni} /$ rutile $>\mathrm{Ni} / \mathrm{TiO}_{2}$. The crystallite size of $\mathrm{TiO}_{2}$ particles of $\mathrm{Ni} / \mathrm{TiO}_{2}-500$ increased on reduction. The crystallite size of $\mathrm{TiO}_{2}$ follows the order of Ni/rutile-500 $>\mathrm{Ni} /$ anatase-500 > $\mathrm{Ni} / \mathrm{TiO}_{2}-500$.

\subsection{Effect of temperature}

The effect of temperature on the conversion of NB has been examined on $\mathrm{Ni}$ impregnated on various phases of titania at $120-150{ }^{\circ} \mathrm{C}$ and at hydrogen pressure of $1.96 \mathrm{MPa}$ (Fig. 6). Interestingly, the conversion of NB proceeded with atom economy to the exclusive formation of AN. An increase in conversion of NB with increasing temperature was observed. At $120^{\circ} \mathrm{C}$, the conversion was lower than $10 \%$ for all the samples. The conversion increased with temperature until $140{ }^{\circ} \mathrm{C}$ and the increase in conversion was steeper at 130 than at $140{ }^{\circ} \mathrm{C}$. The conversion almost remained unchanged at $150{ }^{\circ} \mathrm{C}$ in comparison with $140{ }^{\circ} \mathrm{C}$. The highest conversion of $99 \%$ was exhibited by $\mathrm{Ni} /$ rutile catalyst. As the conversion at 140 and $150{ }^{\circ} \mathrm{C}$ are comparable, further investigation was carried out only at $140{ }^{\circ} \mathrm{C}$. The observed trend for $\mathrm{NB}$ conversion at the temperatures studied is $\mathrm{Ni} /$ rutile $>\mathrm{Ni} /$ anatase $>\mathrm{Ni} / \mathrm{TiO}_{2}$. The enhanced synergistic effect between rutile and $\mathrm{Ni}$ has a stronger influence on the catalytic activity of $\mathrm{Ni} /$ rutile than the other samples. The $\mathrm{Ni} / \mathrm{TiO}_{2}$ catalyst sample was found to possess lower activity than $\mathrm{Ni} /$ anatase and $\mathrm{Ni} /$ rutile. This could be due to the formation of $\mathrm{Ti}_{2} \mathrm{O}_{3}$ moieties in a facile manner in $\mathrm{Ni} / \mathrm{TiO}_{2}$ which may physically block the active nickel sites thereby altering the adsorptive properties of the Ni sites. Although the crystallite size of $\mathrm{Ni}$ supported on $\mathrm{TiO}_{2}$ is smaller (15.4 nm) than on rutile $(16.4 \mathrm{~nm})$ and anatase $(23.3 \mathrm{~nm})$, $\mathrm{Ni} /$ anatase-500 and $\mathrm{Ni} /$ rutile-500 showed higher conversion than $\mathrm{Ni} / \mathrm{TiO}_{2}-500$. This could be due to higher concentration

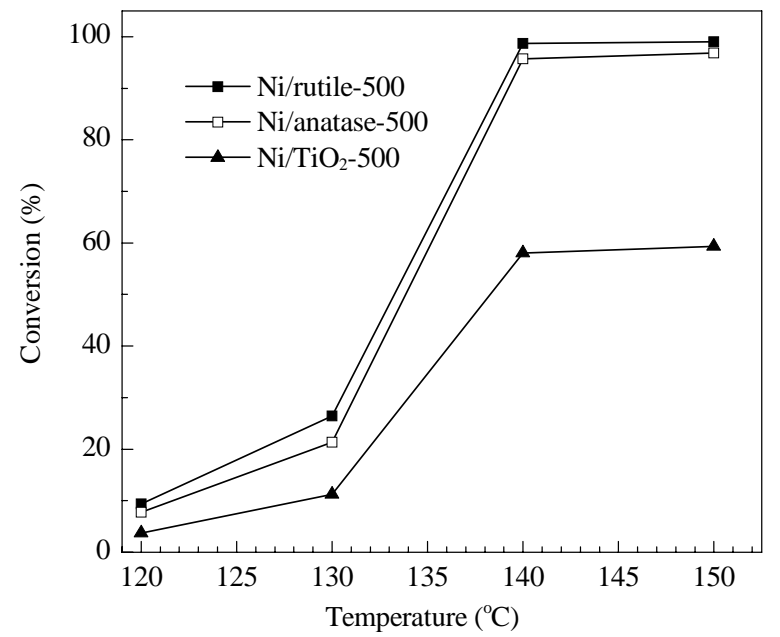

Fig. 6. Effect of temperature on the conversion of nitrobenzene on $\mathrm{Ni}$ supported on various phases of titania. Reaction conditions: $15 \% \mathrm{Ni}$ loading, 0.15 g catalyst, $1.96 \mathrm{MPa}_{2}$ pressure, $400 \mathrm{r} / \mathrm{min}$. of nickel on the surface of anatase and rutile than on $\mathrm{TiO}_{2}$ suggesting that they serve as effective supports for the preparation of reduction catalysts.

\subsection{Effect of pressure}

In the liquid phase hydrogenation, hydrogen pressure is a significantly important parameter, as hydrogen serves as one of the reactants. The effect of hydrogen pressure on the conversion of $\mathrm{NB}$ on $\mathrm{Ni}$ supported on various phases of titania at $140{ }^{\circ} \mathrm{C}$ is shown in Fig. 7. The conversion was found to increase with $\mathrm{H}_{2}$ pressure up to $1.96 \mathrm{MPa}$ and remains almost unchanged at 2.45 MPa. The observed order for the conversion of $\mathrm{NB}$, irrespective of $\mathrm{H}_{2}$ pressure, is $\mathrm{Ni} /$ rutile $>\mathrm{Ni}$ /anatase $>\mathrm{Ni} / \mathrm{TiO}_{2}$. A maximum conversion of $99 \%$ was exhibited by $\mathrm{Ni} /$ rutile at $1.96 \mathrm{MPa}$. As the conversion of NB tends to stabilize at $1.96 \mathrm{MPa}$, further experiments were performed at this hydrogen pressure only. The selectivity for $\mathrm{AN}$ is $100 \%$ at all hydrogen pressures for all the catalysts. The remarkable enhancement in conversion of NB with $\mathrm{H}_{2}$ pressure illustrates the preferential adsorption of hydrogen on the surface of the catalyst over NB. Thus the adsorption of hydrogen on the catalyst surface seems to be a key first step in the hydrogenation of NB and thereby the rate of hydrogenation appears to depend only on the adsorption of hydrogen on the catalyst surface. The presence of NB in the solvent phase seems to lend support to this point.

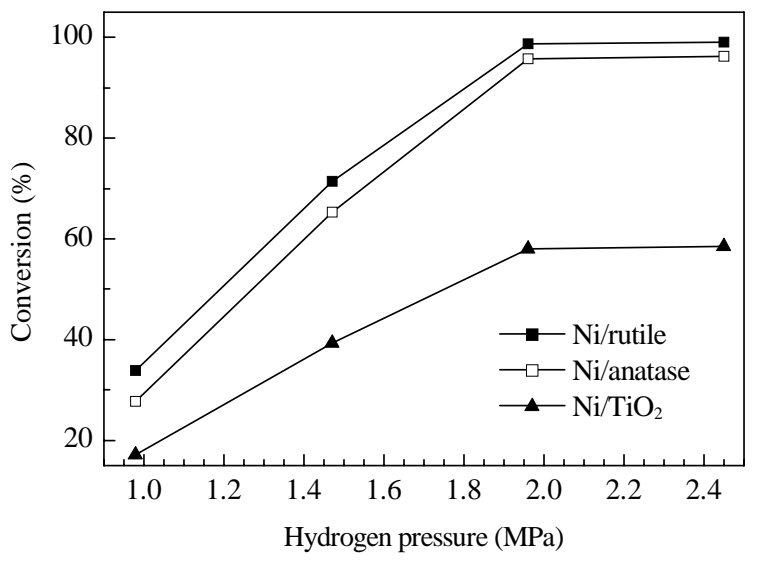

Fig. 7. Effect of pressure on the conversion of nitrobenzene on $\mathrm{Ni}$ supported on various phases of titania. Reaction conditions: $15 \% \mathrm{Ni}$ loading, 0.15 g catalyst, $140{ }^{\circ} \mathrm{C}, 400 \mathrm{r} / \mathrm{min}$.

\subsection{Effect of Ni loading}

Nickel was supported on $\mathrm{TiO}_{2}$, anatase, and rutile by conventional impregnation using an aqueous solution of $\mathrm{Ni}\left(\mathrm{NO}_{3}\right)_{2} \cdot 6 \mathrm{H}_{2} \mathrm{O}$. The Ni content was varied from 5 to 20 wt\%. Catalysts, after drying at $100{ }^{\circ} \mathrm{C}$, were subjected to calcination at $500{ }^{\circ} \mathrm{C}$ in air and thereafter to reduction at 450 ${ }^{\circ} \mathrm{C}$ for $4 \mathrm{~h}$ in flowing hydrogen. Figure 8 shows the effect of 


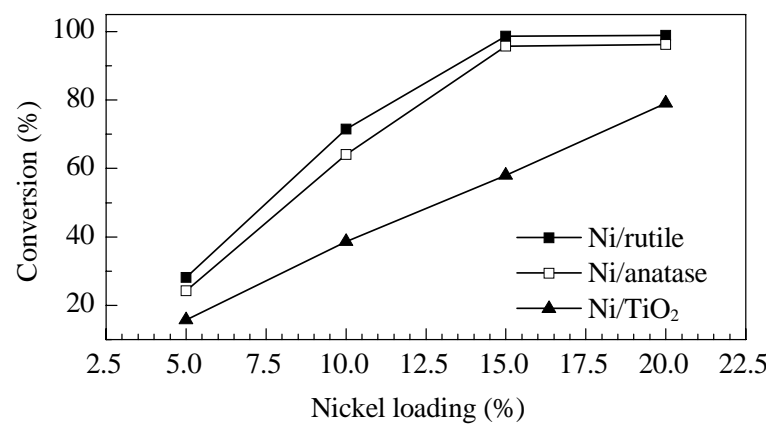

Fig. 8. Effect of nickel loading on the conversion of nitrobenzene on Ni supported on various phases of titania. Reaction conditions: $0.15 \mathrm{~g}$ catalyst, $140{ }^{\circ} \mathrm{C}, 1.96 \mathrm{MPa} \mathrm{H}_{2}$ pressure, $400 \mathrm{r} / \mathrm{min}$.

Ni loading on the conversion of NB. The experimental conditions used are: $140{ }^{\circ} \mathrm{C}, 1.96 \mathrm{MPa}$ hydrogen pressure, and reaction duration of $1 \mathrm{~h}$. The catalytic activity of the samples is found to increase with increasing $\mathrm{Ni}$ content for $\mathrm{Ni} /$ rutile and $\mathrm{Ni} /$ anatase up to $15 \%$ loading and levels off at $20 \%$ loading. Interestingly, $\mathrm{Ni} / \mathrm{TiO}_{2}$ displays an increase in the catalytic activity with $\mathrm{Ni}$ loading. The conversion was found to increase at $20 \%$ loading unlike $\mathrm{Ni} /$ rutile and $\mathrm{Ni} /$ anatase, and a conversion of about $80 \%$ could be achieved. The increase in conversion is attributed to the presence of more nickel active sites on the surface of the catalyst. The observed order for the conversion of NB for various $\mathrm{Ni}$ loading is $\mathrm{Ni} /$ rutile $>\mathrm{Ni} /$ anatase $>\mathrm{Ni} / \mathrm{TiO}_{2}$. The selectivity for AN was found to be $100 \%$ at all Ni loadings. As the highest possible conversion was reached at $15 \% \mathrm{Ni}$ loading for $\mathrm{Ni} /$ rutile and $\mathrm{Ni} /$ anatase, all the experiments were carried out at $15 \% \mathrm{Ni}$ loading.

\subsection{Effect of catalyst amount}

The amount of the catalyst was changed from 0.05 to $0.15 \mathrm{~g}$ in order to study its effect on the conversion of NB (Fig. 9). The experimental conditions employed were 140 ${ }^{\circ} \mathrm{C}, 1.96 \mathrm{MPa}$ hydrogen pressure, $1 \mathrm{~h}$. The conversion was

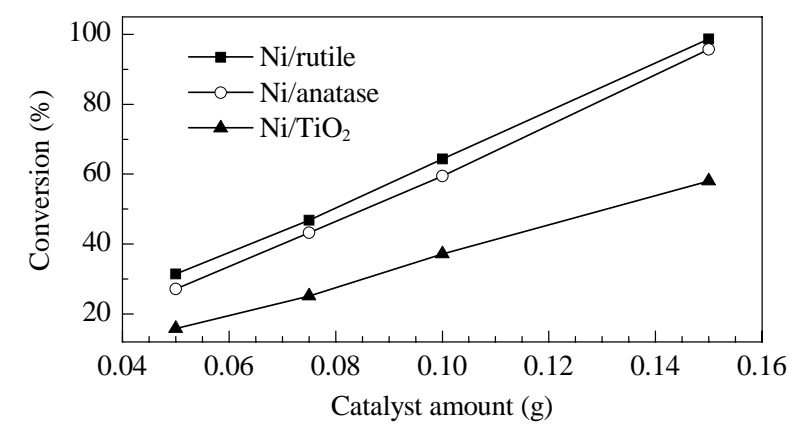

Fig. 9. Effect of quantity of catalyst on the conversion of nitrobenzene on Ni supported on various phases of titania. Reaction conditions: $15 \%$ Ni loading, 0.15 g catalyst, $140{ }^{\circ} \mathrm{C}, 1.96 \mathrm{MPa} \mathrm{H}_{2}$ pressure, 400 $\mathrm{r} / \mathrm{min}$. found to increase almost proportionately with increase in the catalyst amount for all the samples. The enhanced conversion with the amount of catalyst is attributed to improved the contact of the catalyst with reactants.

\subsection{Catalyst stability}

The conversion of NB with time was monitored by performing the reaction at $140{ }^{\circ} \mathrm{C}$ and $1.96 \mathrm{MPa}$ hydrogen pressure (Fig. 10) with a view to measure the stability of the catalysts. The reaction was performed for $10 \mathrm{~h}$. At every hour, the reaction effluent was decanted and analyzed on GC, while the autoclave containing spent catalyst was charged with fresh reactants and the reaction was continued. It was observed that the conversion decreased with time on stream by $3.4 \%, 5.8 \%$, and $13.8 \%$, respectively, for $\mathrm{Ni} /$ rutile-500, $\mathrm{Ni} /$ anatase-500 and $\mathrm{Ni} / \mathrm{TiO}_{2}-500$ at the end of $10 \mathrm{~h}$. It may be noted that the drop in the conversion was not significant up to $5 \mathrm{~h}$. The observed data shows that the activity is only marginally lost on Ni/rutile-500 and $\mathrm{Ni} /$ anatase-500 in comparison with $\mathrm{Ni} / \mathrm{TiO}_{2}-500$. The higher activity of $\mathrm{Ni} /$ rutile-500 could be due to the strong metal support interaction between $\mathrm{Ni}$ and rutile, arising from high surface enthalpy and unsatisfied charges on rutile. The electron density on $\mathrm{Ni}$ is altered as a result of electron transfer between $\mathrm{Ni}$ and rutile. The interaction between $\mathrm{Ni}$ and $\mathrm{Ti}^{3+}$ may generate negative charge on $\mathrm{Ni}$ atoms which may enhance the activity of $\mathrm{Ni} /$ rutile for the hydrogenation of NB. It is worth mentioning that AN was the exclusive product formed with time on stream for all the samples.

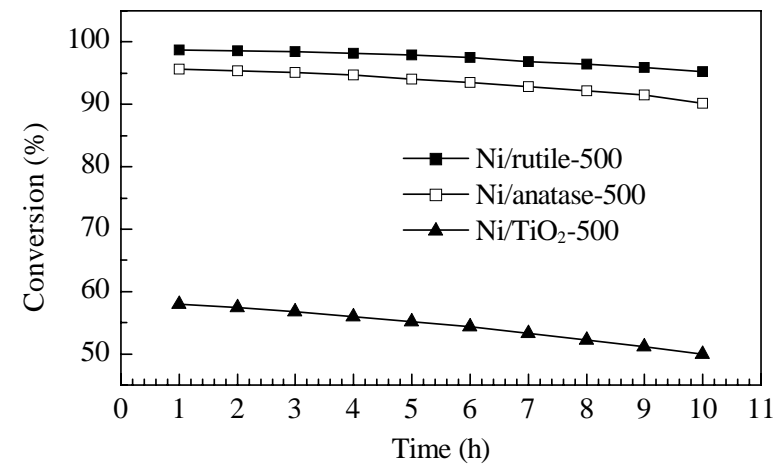

Fig. 10. Catalyst stability of nitrobenzene on Ni supported on various phases of titania. Reaction conditions: $15 \%$ Ni loading, 0.15 g catalyst, $140{ }^{\circ} \mathrm{C}, 1.96 \mathrm{MPa} \mathrm{H}_{2}$ pressure, $400 \mathrm{r} / \mathrm{min}$.

\subsection{Hydrogenation of nitrobenzene}

The hydrogenation of NB is anticipated to take place via the initial formation of nitrosobenzene, which subsequently reduced to phenylhydroxylamine. The phenylhydroxylamine is further reduced to form AN. The NB molecule possesses two reducible centers viz., $\mathrm{N}=\mathrm{O}$ group and an aromatic ring 
and in principle one could observe a mix of reduced products and the completely reduced product. The reduction of NB performed on Ni supported titania catalysts under different experimental conditions in this investigation clearly demonstrates the lone formation of AN. Interestingly, the selectivity for AN is $100 \%$ irrespective of the nature of titania phase and the extent of Ni loading. The hydrogenation of aromatic ring requires about 25 times higher energy $\left(22.4 \mathrm{~kJ} / \mathrm{mol}\right.$ at $\left.25{ }^{\circ} \mathrm{C}\right)$ than the hydrogenation of $\mathrm{N}=\mathrm{O}$ group $(-552.8 \mathrm{~kJ} / \mathrm{mol}$ at 25 ${ }^{\circ} \mathrm{C}$ ) in NB. Also, the hydrogenation of aromatic ring in NB requires the adsorption of benzene ring on the surface of the catalyst. It may be noted that on a polar support like $\mathrm{TiO}_{2}$, the adsorption of $\mathrm{C}=\mathrm{C}$ or benzene is less likely in comparison with the adsorption of $\mathrm{N}=\mathrm{O}$ group.

The activity of various phases of titania is found to be different which shows that the strength of adsorption of $\mathrm{N}=\mathrm{O}$ group or the concentration of nickel hydride on the surface is different on the various phases of titania. As described under effect of $\mathrm{H}_{2}$ pressure section, hydrogen is adsorbed on the surface of the catalyst to form nickel hydrides. This activated $\mathrm{H}$ species may attack the $\mathrm{N}=\mathrm{O}$ group of $\mathrm{NB}$ leading to AN formation. Alternatively, the partially reduced $\mathrm{TiO}_{x}$ species (with oxygen vacancies) present in interfaces are assumed to co-ordinate with the oxygen atom of the $\mathrm{N}=\mathrm{O}$ group leading to the hydrogenation of the $\mathrm{N}=\mathrm{O}$ bond.

The selectivity for AN is nearly same on all the catalysts. However the conversion of $\mathrm{NB}$ is halved on $\mathrm{Ni} / \mathrm{TiO}_{2}$ when compared with $\mathrm{Ni} /$ anatase and $\mathrm{Ni} /$ rutile. The dispersion of $\mathrm{Ni}$ supported on a high surface area titania is found to be greater than on anatase and rutile. It is worthy to note that the conversion of NB is increased with decreasing dispersion of Ni. The observed catalytic activity trend for these catalysts possibly suggests that a higher dispersion of $\mathrm{Ni}$ has detrimental effect. This explains the significance of surface concentration of $\mathrm{Ni}$ atoms in determining the conversion of $\mathrm{NB}$ on titania.

\section{Conclusions}

The catalytic activity of Ni impregnated on various phases of titania for the reduction of NB has been evaluated. The XRD profiles of the reduced catalyst samples show the presence of fcc phase Ni on the surface. A lower peak reduction temperature in TPR for Ni/rutile suggests its greater reducible property. A higher complete reduction temperature for $\mathrm{Ni} /$ rutile points out a strong metal-support interaction. It was observed that the surface area of unmodified titania is greatly reduced on impregnation with $\mathrm{Ni}$ and the surface area of the reduced catalyst samples follow the order of $\mathrm{Ni} / \mathrm{TiO}_{2}>$ $\mathrm{Ni} /$ rutile $>\mathrm{Ni}$ /anatase. The conversion was found to increase with temperature and reaches a plateau at higher temperatures. The observed order at all reaction temperatures was
$\mathrm{Ni} /$ rutile $>\mathrm{Ni} /$ anatase $>\mathrm{Ni} / \mathrm{TiO}_{2}$. Interestingly, $\mathrm{AN}$ is the only product formed which suggests the hydrogenation of NB proceeds with atom economy. The conversion was found to be optimum at $140{ }^{\circ} \mathrm{C}, 1.96 \mathrm{MPa}_{2}$ pressure, and $15 \% \mathrm{Ni}$ loading. A higher $\mathrm{Ni}$ dispersion seems to have a detrimental effect on the conversion. An increase in conversion with $\mathrm{H}_{2}$ pressure suggests preferential adsorption of $\mathrm{H}_{2}$ on $\mathrm{Ni}$ present on the catalytic surface, forming $\mathrm{Ni}-\mathrm{H}$ species. The hydrogenation of nitrobenzene may also be facilitated by the oxygen-deficient $\mathrm{TiO}_{x}$ species present in the catalyst through interaction with $\mathrm{N}=\mathrm{O}$ group. The conversion dropped only marginally when the experiment was run for $10 \mathrm{~h}$ in case of $\mathrm{Ni}$ /rutile and $\mathrm{Ni}$ /anatase suggesting a good catalytic stability.

\section{References}

1 Travis A S. In Rappoport Z ed. The Chemistry of Functional Groups: The Chemistry of Anilines. Weinheim: Wiley-VCH, 2007. 715

2 Blaser H U, Siegrist U, Studer M. In: Sheldon R A ed. Fine Chemicals Through Heterogeneous Catalysis. Weinheim: van Bekkum, Wiley-VCH, 2001. 389

3 Nishimura S ed. Handbook of Heterogeneous Catalytic Hydrogenation for Organic Synthesis. Weinheim: Wiley-VCH, 2001. 332

4 Rahaim R J, Maleczka R E. Org Lett, 2005, 7: 5087

5 Motoyama Y, Kamo K, Nagashima H. Org Lett, 2009, 11: 1345

6 Brinkman H R, Miles W H, Hilborn M D, Smith M C. Synth Commun, 1996, 26: 973

7 de Noronha R G, Romao C C, Fernandes A C. J Org Chem, 2009, 74: 6960

8 Holler V, Wegricht D, Yuranov I, Kiwi-Minsker L, Renken A. Chem Eng Technol, 2000, 23: 251

9 Zhao F, Ikushima Y, Arai M. J Catal, 2004, 224: 479

10 Lee H Y, An M. Bull Korean Chem Soc, 2004, 25: 1717

11 Khan F A, Sudheer C. Tetrahedron Lett, 2009, 59: 3394

12 Zhou Y, Li J, Liu H, Zhao L, Jiang H. Tetrahedron Lett, 2006, 47: 8511

13 Iyer S, Kulkarni G M. Synth Commun, 2004, 34: 721

14 Junge K, Wendt B, Shaikh N, Beller M. Chem Commun, 2010, 46: 1769

15 Enthaler S, Junge K, Beller M. Angew Chem, Int Ed, 2008, 47: 3317

16 Li H, Zhao Q, Wan Y, Dai W, Qiao M. J Catal 2006, 244: 251

17 Xu R, Xie T, Zhao Y G, Li Y D. Nanotechnology, 2007, 18: 55602

18 Vilella I M J, de Miguel S R, Scelza O A. Chem Eng J, 2005, 114: 33

19 Sun Z, Zhao Y, Xie Y, Tao R, Zhang H, Huang C, Liu Z. Green Chem, 2010, 12: 1007

20 Meng X, Cheng H, Akiyama Y, Hao Y, Qiao W, Yu Y, Zhao F, Fujita S, Arai M. J Catal, 2009, 264: 1

21 Raj K J A, Ramaswamy A V, Viswanathan B. J Phys Chem C, 2009, 113: 13750 